\begin{tabular}{|c|c|c|}
\hline NA & $\begin{array}{l}\text { Науковий вісник НлТУ України } \\
\text { Scientific Bulletin of UNFU }\end{array}$ & \begin{tabular}{|l|l} 
(c) (i) ISSN 1994-7836 (print) \\
BY ISSN 2519-2477 (online)
\end{tabular} \\
\hline нAт! & https://doi.org/10.36930/40291020 & $@ \bowtie$ Correspondence author \\
\hline & $\begin{array}{l}\text { Article received 21.10.2019 p. } \\
\text { Article accepted 26.12.2019 p. }\end{array}$ & $\begin{array}{r}\text { Yu. R. Dadak } \\
\text { yuriy.dadak@nltu.edu.ua }\end{array}$ \\
\hline & УДк 674:621.928.93 & \\
\hline
\end{tabular}

А. В. Ляшеник ${ }^{1}$, Є. М. Лютий ${ }^{2}$ Л. О. Тисовський ${ }^{2}$ Ю. Р. Дадак ${ }^{2}$

${ }^{1}$ Коломийський політехнічний коледж НУ "Львівська політехніка", м. Коломия, Україна

${ }^{2}$ Національний лісотехнічний університет Украӥни, м. Львів, Украйна

\title{
ТЕОРІЯ І ПРАКТИКА ВИКОРИСТАННЯ ЦИКЛОНІВ НА ДЕРЕВООБРОБНИХ ПІДПРИЄМСТВАХ
}

\begin{abstract}
Теоретично обгрунтовано доцільність зміни геометричних розмірів циклона та на цій основі розроблено нову конструкцію пиловловлювача. Наведено характеристику основним типам циклонів, що використовуються у деревообробній галузі. Проаналізовано наявні підходи до математичного моделювання аеродинамічних процесів у циклонах. Наведено нову математичну модель руху запиленого повітря всередині сепаратора, яка грунтується на сумісному розгляді рівнянь Нав'є-Стокса для в'язкої стисливої рідини (газу), рівняння нерозривності, рівнянь стану і рівнянь балансу тепла. Для циклону типу ЦН15 записано початкові і граничні умови. Розв'язано отриману повну систему диференціальних рівнянь у частинних похідних та досліджено вплив геометричних розмірів сепаратора на експлуатаційні показники апарату. Числовий аналіз задачі проведено для циклона з фіксованими геометричними параметрами. Досліджено залежність гідравлічного опору циклона від таких параметрів, як висота циліндричної частини, глибина занурення вихлопної труби, висота конічної частини, діаметр вихлопної труби, діаметр пиловипускного патрубка. Досліджено розподіл статичного тиску всередині корпуса циклона. Під час досліджень розглядали різні діаметри пиловипускного отвору, а також різні значення висоти циліндричної частини. Досліджено поле швидкостей запиленого потоку всередині пиловловлювача, зокрема, iї тангенціальна та осьова складові. На основі розробленої математичної моделі побудовано ізолінії швидкості потоку у характерних площинах, які проходять через вертикальну вісь циклона. Для підтвердження адекватності запропонованої математичної моделі результати числового аналізу підтверджено експериментальними дослідженнями. Для цього розроблено конструкцію експериментального стенда для проведення досліджень, у якій передбачено можливість зміни висоти циліндричної частини, глибини занурення вихлопної труби, площі поперечного перерізу вихлопної труби та використання різних типів конічної частини бункерів.
\end{abstract}

Ключові слова: циклон; запилене повітря; математичне моделювання аеродинамічних процесів; рівняння Нав'є-Стокса.

Вступ. Характерною особливістю деревообробних підприємств під час їх роботи $є$ виділення великої кількості пилу та тирси у навколишне середовище. За показниками забрудненості атмосфери деревообробна галузь входить у першу десятку серед всіх галузей промисловості. Тому розроблення нових високоефективних пристроїв для очищення аспіраційного повітря від деревного пилу набуває важливого як теоретичного, так і практичного значення.

Класичним атрибутом пристроїв для очищення забрудненого повітря на підприємствах деревообробної галузі $є$ циклони. Принцип роботи таких апаратів грунтується на тому, що відокремлення твердих частинок від повітря відбувається за рахунок відцентрової сили, яка діє на частинку пилу, при обертально-поступальномy русі запиленого повітря. Серед найвідоміших конструкцій циклонів, що застосовують у деревообробній промисловості, є циклони Гіпродрева, Гіпродревпрома (Ц), циклони типу "К", ВЦНДІОП, СІОП, НДІОГаза (ЦН-11, -15, -15 у, -24) (рис. 1).
Основними елементами циклона (див. рис. 1) є вхідний патрубок 1 , корпус 2 і вихідний патрубок 3. Запилене повітря, потрапляючи в циклон, здійснює обертовий рух у просторі між поверхнею корпусу циклона i вихлопною трубою. Одночасно 3 обертовим, потік здійснює поступальний рух до конічної частини циклона. Аеродинамічні сили викривляють траєкторії пилових частинок. Під дією відцентрових сил частинки пилу, які мають більшу масу, притискаються до внутрішньої поверхні корпусу i, продовжуючи обертатися навколо осі циклона, рухаються в напрямку до виходу із апарату у бункер.

Основними характеристиками циклона $є$ його коефіцієнт гідравлічного опору та коефіцієнт корисної дії (ефективність). Кожна з конструкцій циклона зорієнтована на конкретні умови його роботи. Існують універсальні циклони (використовують у багатьох технологічних процесах) та спеціалізовані (призначені тільки для визначених умов роботи).

Окрім згаданих, існують й інші конструкції цикло-

Інформація про авторів:

Ляшеник Андрій Васильович, канд. техн. наук, доцент, викладач. Email: Iyashenyk@gmail.com

Лютий Євген Михайлович, д-р техн. наук, професор, кафедра прикладної механіки. Email: lyutyi@gmail.com

Тисовський Любомир Осипович, канд. фіз.-мат. наук, доцент, кафедра прикладної механіки. Email: Tlo10@ukr.net

Дадак Юрій Романович, канд. техн. наук, доцент, кафедра технологій лісопиляння, столярних і дерев'яних будівельних виробів. Email: yuriy.dadak@nltu.edu.ua

Цитування за ДСТУ: Ляшеник А. В., Лютий Є. М., Тисовський Л. О., Дадак Ю. Р. Теорія і практика використання циклонів на деревообробних підприємствах. Науковий вісник НЛтУ України. 2019, т. 29, № 10. С. 97-103.

Citation APA: Lyashenyk, A. V., Lyutyi, Ye. M., Tysovskyi, L. O., \& Dadak, Yu. R. (2019). Theory and practice of cyclone collector use in the woodworking industry. Scientific Bulletin of UNFU, 29(10), 97-103. https://doi.org/10.36930/40291020 
нів (апарати із жалюзійним відокремлювачем, циклони iз водяною плівкою, апарати із регульованими витратами повітря тощо), кожна 3 яких набувала найбільшого застосування на деревообробних підприємствах в певний період. Проте спільними недоліками відомих конструкцій циклонів $є$ високий коефіцієнт гідравлічного опору та низька ефективність процесу повітроочищення від сухого дрібнодисперсного пилу. Саме останній недолік поряд з підвищенням екологічних вимог до деревообробних підприємств приводять до того висновку, що питання теоретичного та експериментального дослідження процесів очищення повітряного потоку у циклоні в умовах деревообробного виробництва все ще залишаються актуальними. Існує потреба в циклонах для транспортних пневмосистем, які порівняно з відомими конструкціями таких апаратів будуть мати нижчий гідравлічний опір та вищу ефективність. Під час розроблення нової конструкції пиловловлювача потрібно також врахувати досвід повітроочищення в інших галузях промисловості, наприклад металургії, будівництві, льонопереробці та ін.

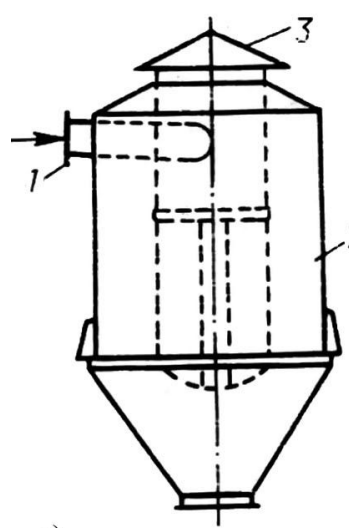

a)

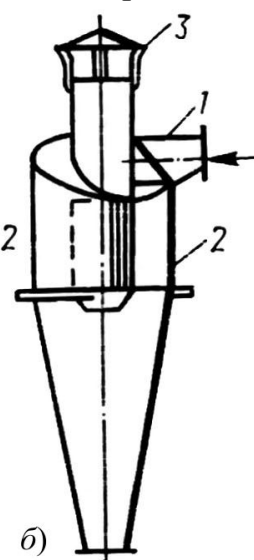

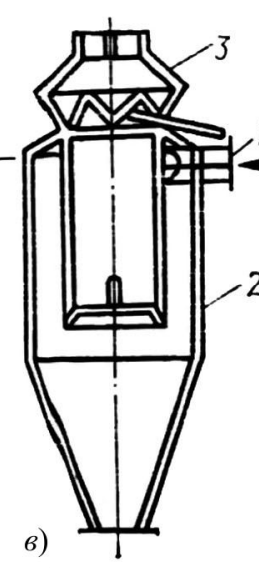

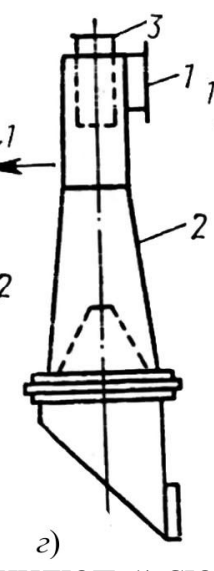

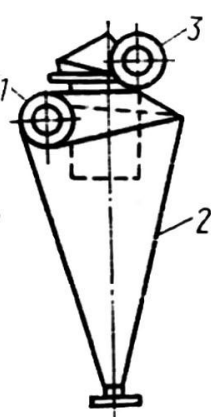

d)

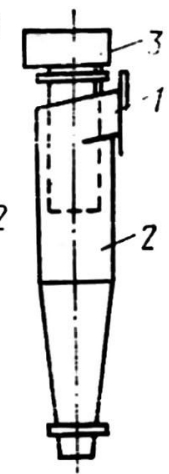

e)

Рис. 1. Схеми циклонів: a) Гіпродрева; б) Гіпродревпрома; в) типу "К"; г) ВЦНДІОП; д) СІОП; е) НДІОгазу; 1) вхідний патрубок; 2) корпус; 3) вихідний патрубок

Підходи до математичного моделювання аеродинамічних процесів у циклонах. Незважаючи на відносну простоту конструкції циклона, аеродинамічні процеси, що відбуваються всередині апарату, є надзвичайно складними. Тому не дивно, що внаслідок відсутності чіткої математичної моделі, яка враховувала б конструктивні параметри циклона та характеристики повітряного потоку на вході у апарат, виникла велика кількість різноманітних конструкцій, ефективність яких $\epsilon$ сумнівною. 3 моменту винайдення циклонів погляди на процес уловлення пилу постійно зазнавали змін. Базовою сепараційною зоною циклона вважали вихлопну трубу, циліндричну чи конічну його частини. Основними теоріями процесу були гравітаційна, відцентрова, моделювання на основі рівнянь гідрогазодинаміки. Так у гравітаційній теорії (Pirumov, 1981) припускалося, що незалежно від ефективності сепараційного процесу, всередині апарату розмір частинок, які можуть бути винесені з циклона, визначається швидкістю газів, які виходять через вихлопну трубу. Розрахункові формули, отримані при цьому, мали в основному емпіричний характер і були дуже наближеними.

Дещо точнішою виявилася теорія циклонної сепарації (Pirumov, 1981), яка грунтувалася на результатах експериментальних випробувань. Вводили припущення, що сила інерції частинки дорівнює відцентровій силі, що виникає в обертальному русі потоку. Також вважали, що радіальна швидкість частинки відрізняється від радіальної швидкості газового потоку. Тангенціальна швидкість руху частинки в кожний момент дорівнює швидкості руху газу в цій точці. Було отримано наближені залежності для визначення часу перебування частинки пилу у циклоні.

Важливий крок до розуміння аеродинаміки циклонів зробив О. I. Пірумов (Pirumov, 1981), який отримав диференціальне рівняння руху частинки пилу в криволінійному потоці у такому вигляді:

$$
\frac{d \vec{V}}{d t}=\frac{1}{\tau}(\vec{W}-\vec{V})=-\frac{1}{\tau} \vec{V}_{C}
$$

де: $\vec{V}$ - абсолютна швидкість руху частинки відносно нерухомої системи координат; $\vec{W}$ - середня швидкість потоку; $\vec{V}_{C}-$ відносна швидкість руху частинки; $\tau=\frac{m}{3 \pi \mu d}=\frac{d^{2}}{18 \mu} \rho-$ величина, яка має розмірність часу $\mathrm{i}$ називається часом релаксації частинки; $m$ - маса частинки; $d$ - діаметр частинки пилу; $\rho$ - густина матеріалу частинки

Якщо врахувати, що частинка пилу здійснює у сепараторі складний рух, причому переносний рух $є$ обертальним, тобто виникає прискорення Кореоліса, то рівняння (1) можна подати так:

$$
\frac{d \vec{V}_{c}}{d t}+\vec{\omega} \times(\vec{\omega} \times \vec{R})+\left(\frac{d \vec{\omega}}{d t} \times \vec{R}\right)+2\left(\vec{\omega} \times \vec{V}_{c}\right)=-3 \pi \mu d v_{c},
$$

де $\omega$ - миттєва кутова швидкість частинки пилу, яка збігається із кутовою швидкістю обертання газового потоку навколо осі циклона. У межах цього підходу в роботах (Liutyi, et al., 2002, 2003) досліджено процеси переміщення запиленого повітря у циклонах із фільтрувальною зовнішньою стінкою, зокрема побудовано траєкторії руху частинки пилу всередині апарата.

Основними недоліками описаних вище теорій $є$ те, що вони:

- не враховують конструктивні особливості циклона;

- досліджують рух частинки тільки у циліндричній частині циклона, або у вихлопній трубі;

- результати обчислення діаметра найменших частинок пилу, які будуть уловлені в циклоні, відповідно до описаних теорій, $€$ завищеними;

- розглядають рух виключно окремої частинки пилу і нехтують взаємодією частинок між собою та зі стінкою апарата.

Найповніше аеродинамічні процеси, що відбуваються у сепараторах, можна описати за допомогою дифе- 
ренціальних рівнянь у частинних похідних, що представляють собою ті чи інші моделі механіки рідин і газів (Loitcianskii, 1978). Зупинимося детальніше на цьому підході.

Математична модель руху запиленого повітря у циклоні. Для визначення основних параметрів сепаратора важливим $\epsilon$ аналіз руху запиленого повітря в циклоні. Процеси, що при цьому відбуваються, внаслідок їх складності, і до сьогодні не вдалося повною мірою теоретично обгрунтувати.

Припустимо, що запилена газова суміш в циклоні здійснює ламінарний рух і є гомогенним середовищем, поведінку якого можна описати моделлю в'язкої стискуваної рідини (газу). Тоді повна система рівнянь для аналізу аеродинамічних процесів у сепараторі складається з рівнянь Нав'є-Стокса, рівняння нерозривності, рівнянь стану і рівняння балансу тепла, які можна подати так.

Рівняння Нав'є-Стокса є основними рівняннями динаміки в'язкого газу й у векторному записі мають такий вигляд:

$$
\rho \frac{d \vec{V}}{d t}=\rho \vec{F}-\operatorname{grad}\left(p+\frac{2}{3} \mu \operatorname{div} \vec{V}\right)+2 \operatorname{Div}(\mu \dot{S}),
$$

де: $\vec{V}(u, v, w)$ - вектор швидкості точки суцільного середовища 3 координатами $x, y, z$ в момент часу $t$ (змінні Ейлера $) ; \quad u=u(x, y, z, t), v=v(x, y, z, t), w=w(x, y, z, t)-$ проекції вектора швидкості на осі нерухомої декартової системи координат; $p=p(x, y, z, t)$ - тиск середовища в точці $з$ координатами $(x, y, z)$ у момент часу $t ; \rho=\rho(x, y, z, t)$ - густина середовища в точці 3 координатами $(x, y, z)$ у момент часу $t ; F=\left(F_{x}, F_{y}, F_{z}\right)-$ вектор густини масової сили; $\operatorname{div} \vec{V}=\frac{\partial u}{\partial x}+\frac{\partial v}{\partial y}+\frac{\partial w}{\partial z}-$ дивергенція вектора швидкості $\vec{V} ; \operatorname{grad} \phi=\left(\frac{\partial \phi}{\partial x}, \frac{\partial \phi}{\partial y}, \frac{\partial \phi}{\partial z}\right)$ - градієнт скалярного поля функції $\phi ; \mu$ - динамічний коефіцієнт в'язкості; $\dot{S}-$ тензор швидкості деформації.

Рівняння нерозривності є математичним записом закону збереження маси певного об'єму суцільного середовища і має вигляд

$$
\frac{\partial \rho}{\partial t}+\operatorname{div}(\rho \vec{V})=0
$$

Рівняннями стану в механіці суцільного середовища називають рівняння, що зв'язують між собою основні фізичні характеристики середовища (тиск, температуру, густину та ін.) і входять у повну систему залежностей для опису руху деякого об'єму речовини. У випадку в'язкого газу припускають, що газ є досконалим, тобто тиск $p$, густина $\rho$ і абсолютна температура $T$ задовольняють закон Клапейрона

$$
p=\rho R T,
$$

де $R$ - газова постійна, яка для різних газів приймає різні значення.

Досвід показує, що динамічний коефіцієнт в'язкості $\mu €$ функцією тільки абсолютної температури $T$. Найчастіше при цьому використовують степеневу залежність

$$
\frac{\mu}{\mu_{0}}=\left(\frac{T}{T_{0}}\right)^{n},
$$

де $T_{0}$ i $\mu_{0}$ - відповідно абсолютна температура і коефіцієнт в'язкості, що відповідають деякому початковому стану газу.
За Карманом в середньому приймають $n=0,76$.

Невід'ємним атрибутом рівнянь руху в'язкого газу $є$ рівняння балансу тепла, яке можна подати у такому вигляді:

$$
\rho \frac{d}{d t}\left(h+\frac{V^{2}}{2}\right)=\rho \vec{P} \cdot \vec{V}+\frac{\partial p}{\partial t}+\operatorname{div}\left(2 \mu \vec{V} \dot{S}-\frac{2}{3} \mu \vec{V} d i v \vec{V}+\frac{\mu}{\sigma} \operatorname{grad} h\right),(7)
$$

де $h$ - ентальпія (теплова функція), яка задається співвідношенням

$$
h=\int_{0}^{T} c_{p}(T) d T .
$$

Отже, для визначення семи невідомих $u, v, w, p, \rho, \mu$, $T$ отримана система семи рівнянь (3)-(7), яка складає замкнену систему рівнянь руху в'язкого газу (векторне рівняння (3) можна замінити трьома скалярними рівняннями). Незважаючи на велику різноманітність конструкцій циклонів, їх корпуси $є$ комбінацією циліндричних і конічних поверхонь, а тому з практичної точки зору для дослідження аеродинамічних процесів, що відбуваються всередині сепараторів, доцільно використовувати комбінацією циліндричних і конічних поверхонь, а тому з практичної точки зору для дослідження аеродинамічних процесів, що відбуваються всередині сепараторів, доцільно використати не прямокутну декартову систему координат $(x, y, z)$, а циліндричну $(r, \theta$, $z)$. Повну систему рівнянь руху запиленого повітря у скалярній формі у декартовій і циліндричній системах координат наведено у роботах (Tysovskyi, et al., 2010; Dorundiak, et al., 2013) відповідно.

Для отримання розв'язку в конкретній області при інтегруванні системи диференціальних рівнянь потрібно задати початкові і граничні умови. Під початковими умовами розуміють задавання в початковий момент часу поля швидкостей, температури і тиску.

$\mathrm{У}$ момент часу $t=0$ частинки потоку повітря знаходяться у перерізі $z=0$ (рис. 2). Якщо позначити швидкість потоку повітря у вхідному патрубку циклона $V$, то значення складових швидкості потоку повітря для циклона $з$ гвинтовим вхідним патрубком дорівнює:

$$
V_{\theta}=V \cdot \cos \alpha ; V_{z}=V \cdot \sin \alpha ; V_{r}=0,
$$

де $\alpha$ - кут нахилу вхідного патрубка до горизонту (див. рис. 2).

Швидкість потоку повітря у вхідному патрубку $V$, як правило, знаходиться у межах $V=17-25$ м/с залежно від конструкції циклона та технологічних параметрів процесу циклонування. Температуру повітряного потоку у початковий момент часу вважаємо рівною температурі зовнішнього середовища $T=T_{\text {зс }}$, а значення тиску визначається аеродинамічною характеристикою вентилятора.

Для запису граничних умов, які залежать від форми циклона та від особливостей його функціонування, поверхню сепаратора умовно поділили на п'ять вертикальних (I-V) і 3 горизонтальні (VI-VIII) ділянки (див. рис. 2). На кожній такій ділянці задаються умови прилипання і непроникності потоку повітря на поверхнях і не беруть до уваги теплообмін між стінками апарата i довкіллям. Вважають також, що статичний тиск на виході з вихлопної труби циклона дорівнює атмосферному (атмосферний тиск за нормальних умов $P_{a}=$ 101325 Па). 


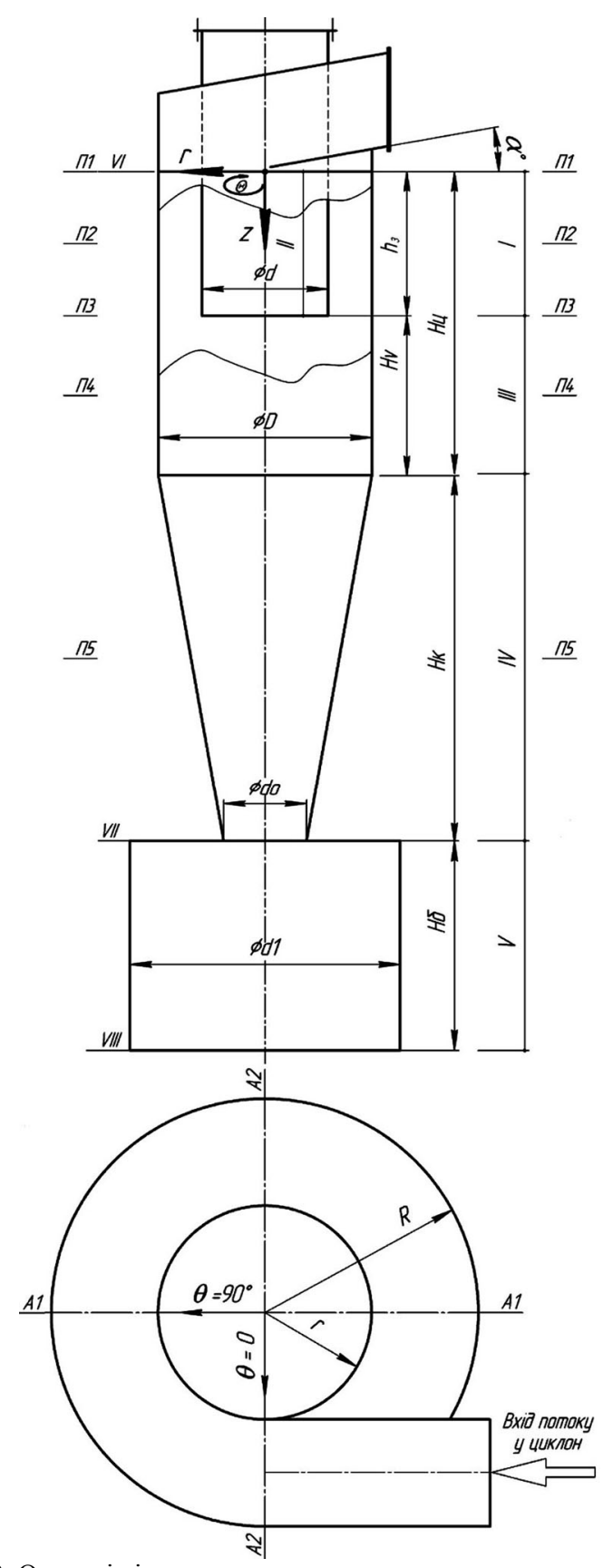

Рис. 2. Основні ділянки циклона для постановки граничних умов

Так, наприклад, для ділянки I (простір між вихлопною трубою та циліндричною частиною апарата), яка обмежена двома циліндричними поверхнями: $r=d / 2+$ 0 та $r=D / 2$, де $d$ - діаметр вихлопної труби, $D$ - діаметр циліндричної частини циклона, граничні умови набувають такого вигляду:

$$
V_{\theta}=0 ; V_{z}=0 ; V_{r}=0 ; \frac{\partial T}{\partial r}=0 .
$$

Аналогічно записуються граничні умови і на інших характерних ділянках поверхні циклона.

Результати числового аналізу. Числовий аналіз задачі проводили для циклона 3 такими геометричними розмірами (див. рис. 2):

- діаметр циклона, $D$ - 400 мм;

- висота циліндричної частини циклона, $H_{\amalg}-650$ мм;

- висота конічної частини циклона, $H_{K}-800$ мм;

- діаметр вихлопної труби, $d-220$ мм;

- глибина занурення вихлопної труби, $h_{3}-316$ мм;

- діаметр пиловипускного отвору, $d_{0}-150$ мм.
Під час розрахунків приймали, що густина повітря $\rho_{n}=1,3 \kappa{ }^{3} \mathrm{M}^{3}$, а температура запиленого потоку повітря $T_{0}=20{ }^{\circ} \mathrm{C}$. Одним із основних показників роботи циклона є гідравлічний опір $\Delta P$, тобто різниця повних тисків у вхідному патрубку та на виході з вихлопної труби апарата. Його значення визначається не лише швидкістю пилоповітряного потоку у вхідному патрубку, але i геометричними розмірами сепаратора. Для моделі циклона, показаної на рис. 2, досліджували залежності гідравлічного опору від таких параметрів, як висота циліндричної частини $\left(H_{Ц}\right)$, глибина занурення вихлопної труби $\left(h_{3}\right)$, висота конічної частини $\left(H_{K}\right)$, діаметр вихлопної труби $(d)$, діаметр пиловипускного патрубка $\left(d_{0}\right)$. Значення $H_{ц}$ змінювали у діапазоні від 200 до 850 мм, значення $h_{3}$ вибирали 3 діапазону 56-716 мм. Деякі із отриманих результатів подано на рис. 3-7.

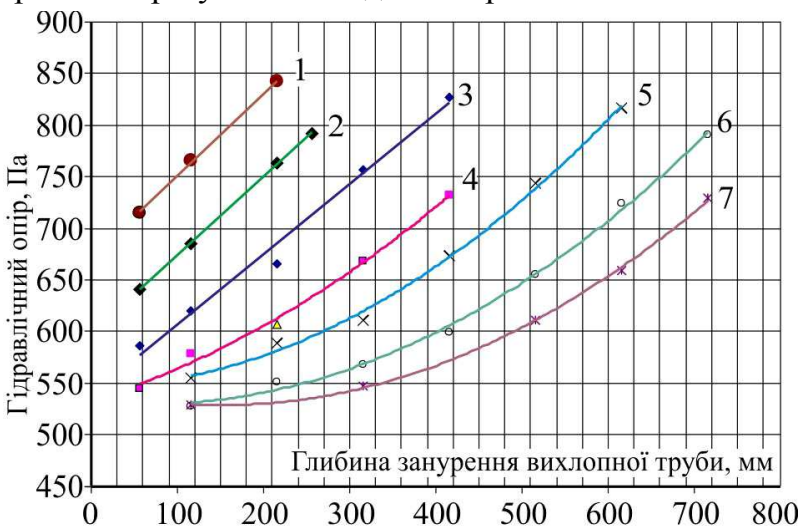

Рис. 3. Залежність гідравлічного опору циклона від глибини занурення вихлопної труби за висоти циліндричної частини 200 мм (крива 1); 250 мм (2); 300 мм (3); 350 мм (4); 400 мм (5); 450 мм (6); 500 мм (7)

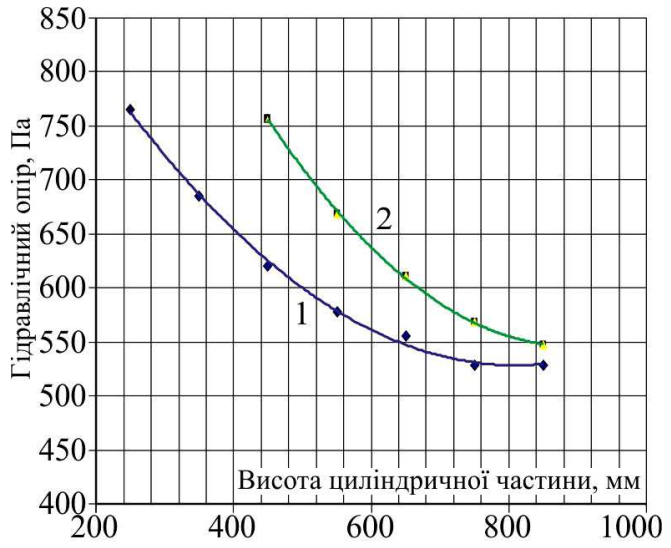

Рис. 4. Залежність гідравлічного опору циклона від висоти циліндричної частини за значень глибини занурення вихлопної труби 116 мм (крива 1) та 316 мм (крива 2)

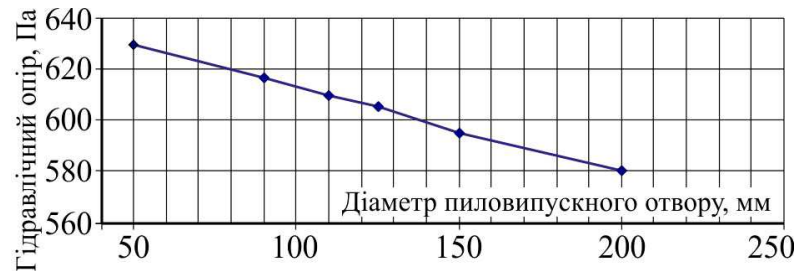

Рис. 5. Залежність гідравлічного опору циклона від діаметра пиловипускного отвору

Розподіл статичного тиску всередині корпусу циклона також є важливою характеристикою, яка впливає на показники роботи циклона. Розподіл тиску в різних перерізах апарата є різним і значення градієнта тиску має великий вплив на ефективність процесу повітро- 
очищення. Досліджено вплив розмірів окремих конструкційних елементів циклона (висота циліндричної частини, глибина занурення вихлопної труби, висота конічної частини, діаметр пиловипускного отвору) на розподіл статичного тиску у апараті. Деякі із результатів цих досліджень подано на рис. 8-11.

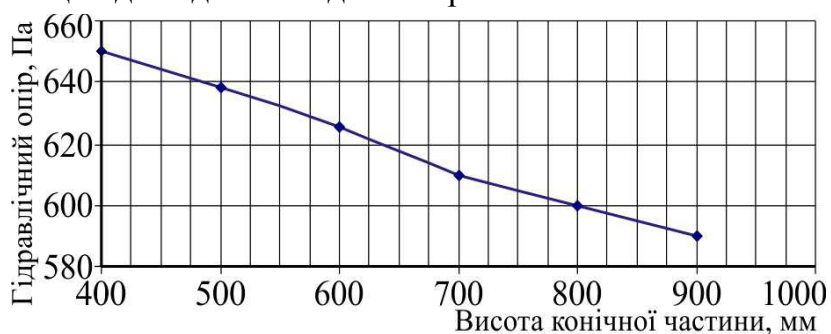

Рис. 6. Залежність гідравлічного опору від висоти конічної частини

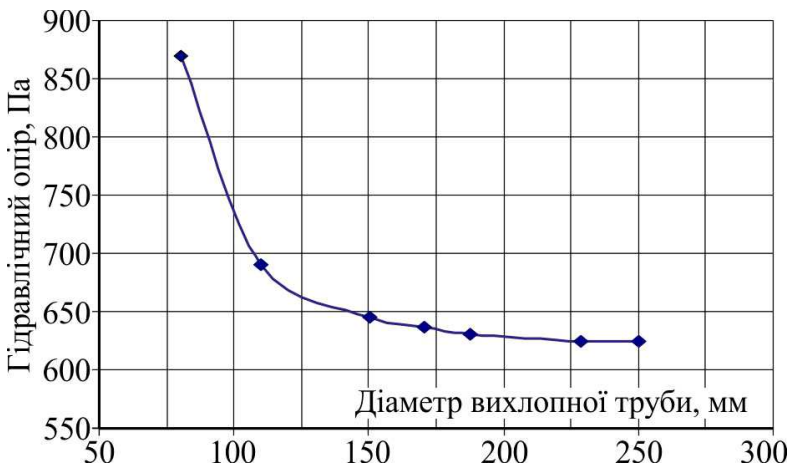

Рис. 7. Залежність гідравлічного опору від діаметра вихлопної труби

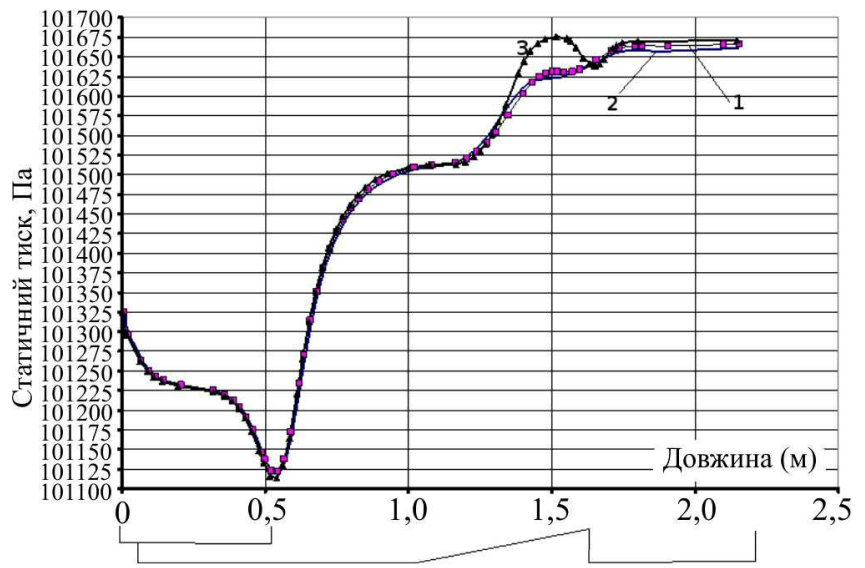

Рис. 8. Розподіл статичного тиску по осі циклона за різних діаметрів пиловипускного отвору: 1) 150 мм, 2) 110 мм, 3) 150 мм

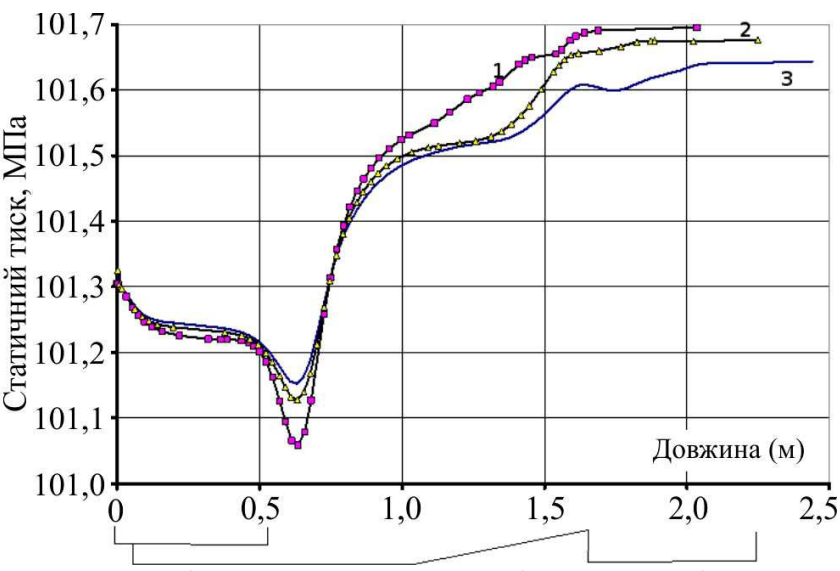

Рис. 9. Розподіл статичного тиску по осі циклона за різних значень висоти циліндричної частини: 1) 300 мм; 2) 600 мм; 3) $800 \mathrm{MM}$

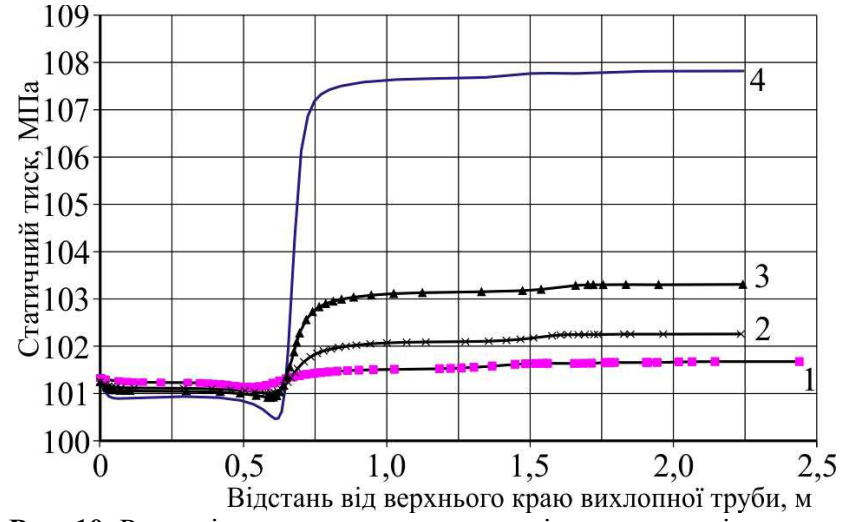

Рис. 10. Розподіл статичного тиску по осі циклона за різних значень діаметра вихлопної труби: 1) 210 мм; 2) 180 мм; 3) 120 мм; 4 - 90 мм

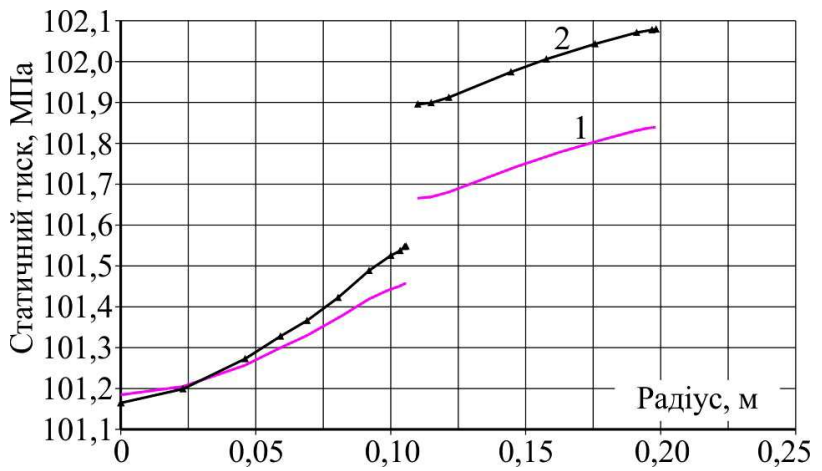

Рис. 11. Розподіл статичного тиску на проміжку від осі до зовнішньої стінки циклона на рівні середини вихлопної труби за різних значень висоти циліндричної частини: 1) 300 мм; 2) 800 мм
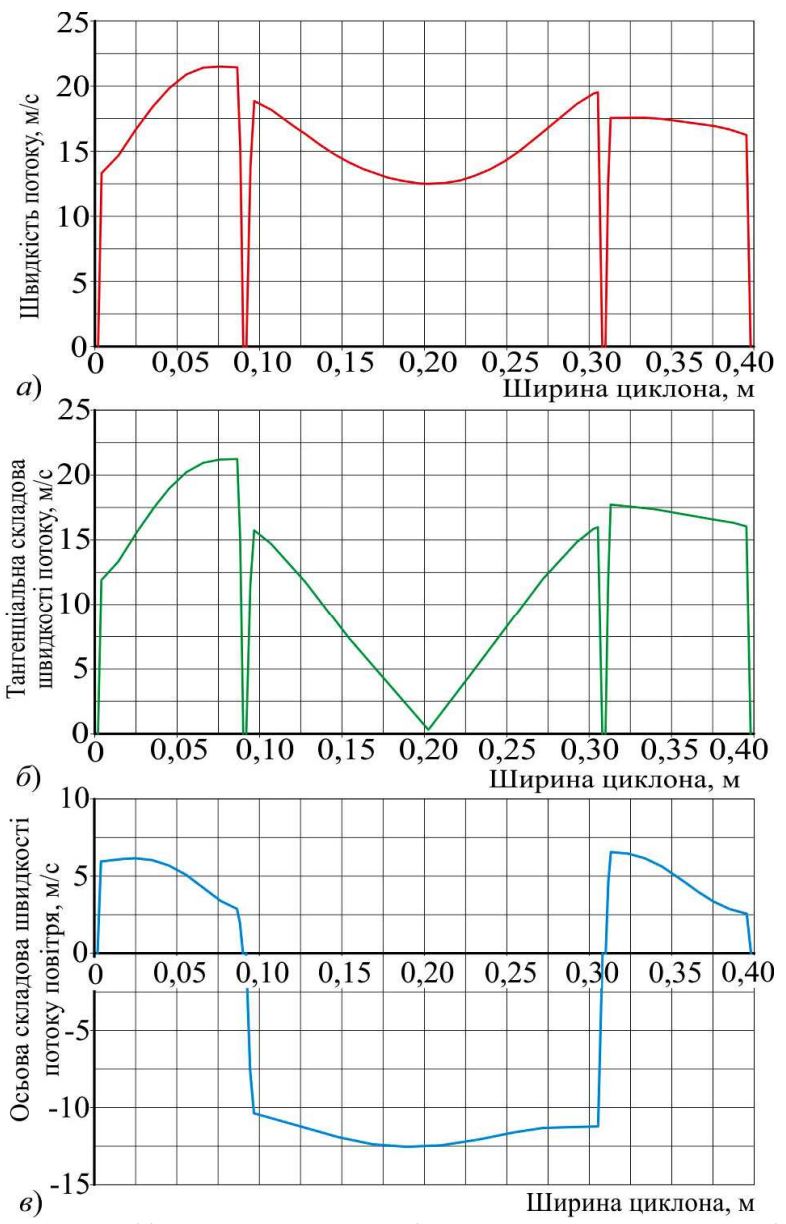

Рис. 12. Графік значень швидкості та ії складових на перетині площин П1 та А2: $a$ ) швидкість потоку; б) тангенціальна складова; в) осьова складова 
Основною аеродинамічною характеристикою процесу сепарації у циклоні $є$ поле швидкостей запиленого потоку повітря всередині пиловловлювача, причому на динаміку процесу сепарації важливий вплив має не тільки значення швидкості потоку в точці, але й значення іiі тангенціальної та осьової складових. Для аналізу простір всередині циклона умовно розділили п'ятьма горизонтальними площинками П1-П5 та двома вертикальними A1-A2 (див. рис. 2). Досліджували розподіл швидкості потоку, іiі тангенціальної та осьової складових на лінії перетину горизонтальної та вертикальної площин. На осі абсцис відкладали відстань $L$ між крайніми стінками циклона. При цьому значення $L=0$ відповідало стінці, яка розташована зліва, а $L=0,4$ м - справа. Як приклад, на рис. 12 представлено графіки швидкості потоку та її складових на лінії перетину площин П1 та А2.

На основі розробленої моделі побудовано ізолінії швидкості потоку у площині $A_{2}$ (рис. 13), яка містить вертикальну вісь циклона і проходить перпендикулярно до напрямку входу потоку в апарат. Найвищі значення швидкості (близько 18,5 м/c) повітряного потоку спостерігаються поблизу краю вихлопної труби. У просторі між вихлопною трубою та зовнішньою стінкою циклона безпосередньо поблизу стінки вихлопної труби значення швидкості знижується до 6,2-8,0 м/с (рис. 14). На самих стінках значення швидкості повітряного потоку та їі складових дорівнює нулю.

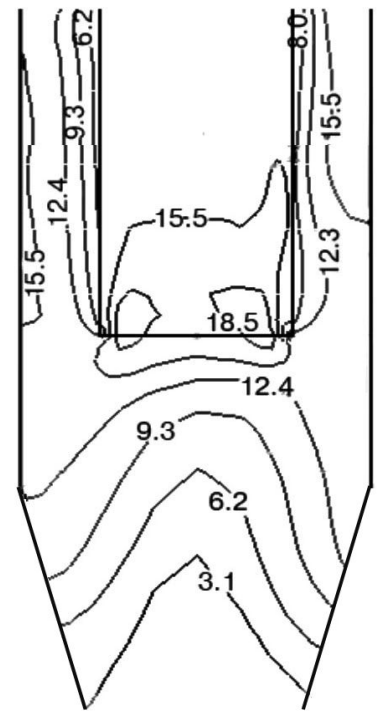

Рис. 13. Ізолінії швидкості повітряного потоку у площині $\mathrm{A} 2$

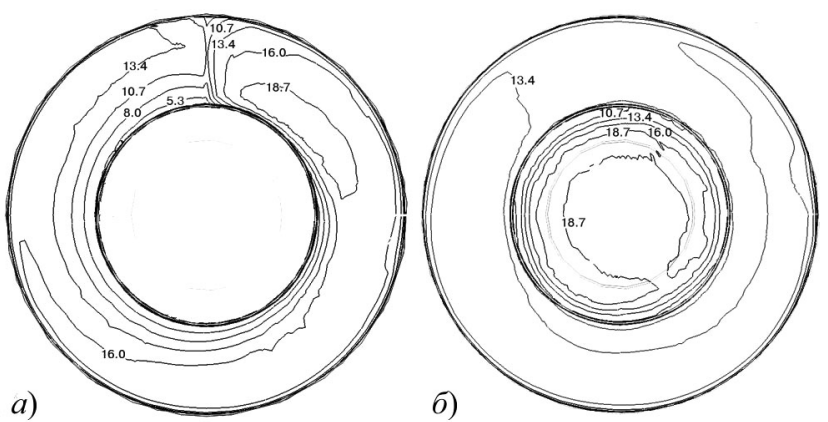

Рис. 14. Ізолінії швидкості повітряного потоку: $a) z=0$; б) $z=h_{3}$

Одночасно з обертальним рухом потік здійснює поступальний рух вниз до конічної частини сепаратора. На початку циліндричної частини проходить перехідний процес між прямолінійним рухом потоку у вхідному патрубку та обертальним рухом у циліндричному корпусі циклона. Тому в просторі між вихлопною трубою та зовнішньою стінкою циклона розподіл швидкості потоку має значне відхилення від симетричності. Симетричним потік можна вважати тільки у просторі, який розміщений нижче від вихлопної труби. У конічній частині проходить зміна напрямку руху потоку. Тут він здійснює поворот на $180^{\circ}$, переходить у внутрішній потік, продовжуючи обертатись підіймається і через вихлопну трубу виходить в атмосферу.

Експериментальні дослідження. Для підтвердження адекватності запропонованої математичної моделі аеродинамічних процесів у циклонах проведено низку експериментальних досліджень. Для цього розроблено конструкцію експериментального стенду циклона (рис. 15.), у якій передбачена можливість зміни висоти циліндричної частини, глибини занурення вихлопної труби, площі перерізу вихлопної труби та використання різних типів конічної частини та бункерів. Під час проведення випробовувань керувалися нормативним документом (Pyleuloviteli, 1967).

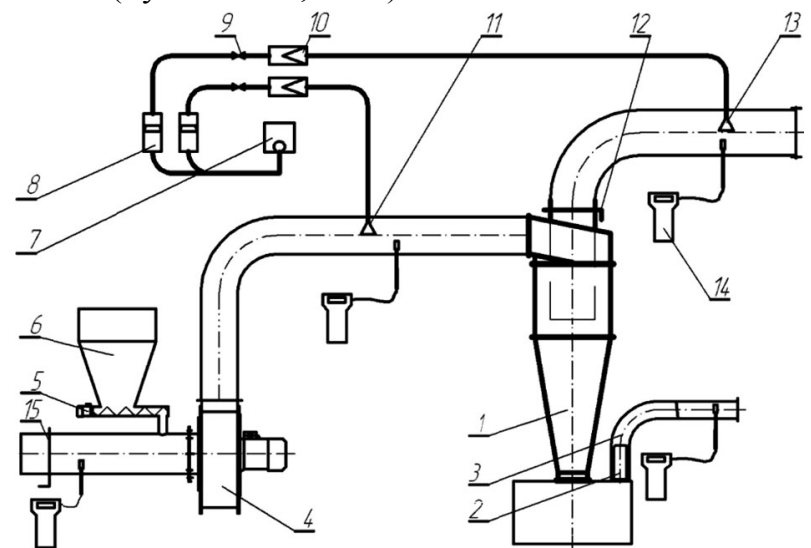

Рис. 15. Схема стенду для випробування циклонів: 1) циклон; 2) фільтрувальний рукав; 3) короб; 4) вентилятор ВРП № 3,15; 5) шнековий живильник; 6) бункер для пилу; 7) вакуум-насос ВН - 461; 8) ротаметр; 9) вентилі; 10 фільтрувальні патрони 3 ковпачками; 11,13) місце відбору пилових проб; 12) шибер; 14) прилад TESTOVENT; 15) шибер

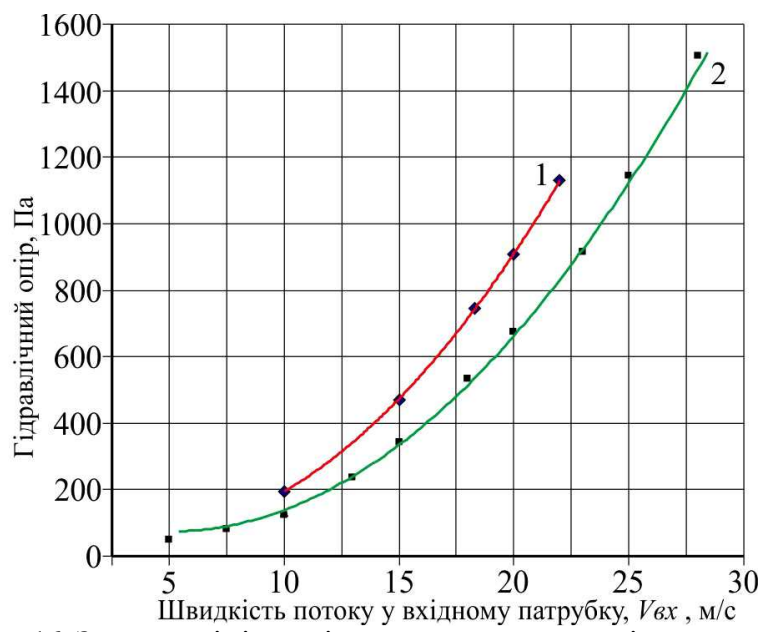

Рис. 16. Залежності гідравлічного опору циклона від швидкості потоку повітря у вхідному патрубку: 1) експериментальна крива; 2) крива математичного моделювання

На рис. 14 (крива 1) представлено залежність гідравлічного опору пиловловлювача від швидкості потоку у вхідному патрубку, отриману експериментальним шляхом. Крива 2 дає ту ж залежність, але отриману шляхом числової реалізації розробленої математичної моделі. Як бачимо, отримані результати є доволі близькими, що свідчить про добру наближеність математичної моделі до опису реальних процесів у циклоні. 


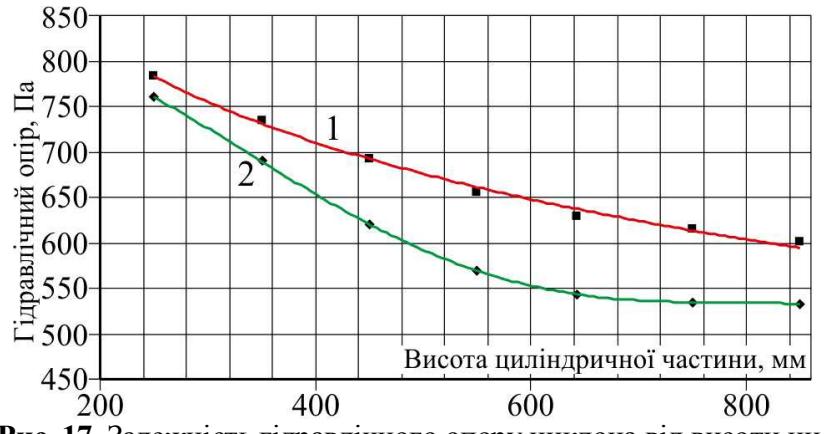

Рис. 17. Залежність гідравлічного опору циклона від висоти циліндричної частини: 1) експериментальна крива; 2) крива математичного моделювання

Результати дослідження залежності гідравлічного опору циклона від висоти його циліндричної частини подані на рис. 17. Крива 1 відображає результати експериментальних досліджень, крива 2 - отримана засобами математичного моделювання. I в цьому випадку отримано добрий збіг результатів.

Проводили й інші експериментальні дослідження. Визначали продуктивність циклона та його ефективність. Розглядали також циклон із фільтрувальною зовнішньою стінкою, для якого визначали співвідношення продуктивності фільтрації і циклонування. Досліджували різні матеріали для вибору фільтрувальної стінки. Результати цих досліджень наведено у роботі (Liutyi, et al., 2009).

Висновки. На основі проведених теоретичних і експериментальних досліджень можна стверджувати таке:

- на деревообробних підприємствах циклони досі залишаються базовими елементами повітроочисних та транспортних пневмосистем, а тому виникає проблема у розробленні нових енергоощадних конструкцій апаратів;

• створення нової математичної моделі руху запиленого повітря у циклоні, яка добре узгоджується із експериментальними дослідженнями, дає змогу істотно заощадити людські і матеріальні ресурси у процесі дослідження впливу геометричних розмірів циклонів і фізичних параметрів пилоповіт- ряного потоку на експлуатаційні і економічні показники роботи таких апаратів;

• надалі плануємо продовжувати дослідження в таких напрямах:

1. Від гомогенного пилоповітряного потоку перейти до двофазного, тобто враховувати у потоці газів наявність твердих частинок деревних відходів;

2. Поряд із ламінарним рухом пилоповітряної суміші розглядати і турбулентні рухи;

3. Узагальнити отримані результати на дослідження аеродинаміки не лише окремих циклонів, а й повітроочисних та транспортних пневмосистем загалом.

\section{References}

Dorundiak, L. M., Liutyi, Ye. M., Tysovskyi, L. O., \& Liashenyk, A. V. (2013). Matematychna postanovka i chyslovyi analiz zadachi pro rukh povitrianoho potoku v tsykloni. Visnyk NTU "KhPI". Seriia: Matematychne modeliuvannia $\mathrm{v}$ tekhnitsi ta tekhnolohiiakh, 5(979), 66-76. [In Ukrainian].

Liutyi, Ye. M., Tysovskyi, L. O, Dadak, Yu. R., \& Liashenyk, A. V. (2009). Tsyklony u derevoobrobnii promyslovosti. Lviv: Redaktsiia zhurnalu "Ukrainskyi pasichnyk", 148 p. [In Ukrainian].

Liutyi, Ye. M., Tysovskyi, L. O., Kondur, O. S., \& Liashenyk, A. V. (2003). Do vyvedennia rivniannia rukhu chastynky pylu u filtruvalnomu tsykloni. Scientific Bulletin of UkrSFU, 13(2), 241-249. [In Ukrainian].

Liutyi, Ye. M., Tysovskyi, L. O., Nakhaiev, P. P., \& Liashenyk, A. V. (2002). Modeliuvannia rukhu chastynky v filtruvalnomu tsykloni. Scientific Bulletin of UkrSFU, 12(8), 131-137. [In Ukrainian].

Loitcianskii, L. G. (1978). Mekhanika zhidkosti i gaza. Moscow: Science, 736 p. [In Russian].

Pirumov, A. I. (1981). Obespylivanie vozdukha. Moscow: Stroiizdat, 296 p. [In Russian].

Pyleuloviteli. (1967). Edinaia metodika sravnitelnykh ispytanii pyleulovitelei dlia ochistki ventiliatcionnogo vozdukha. Leningrad: VNIIOT VTcSPS, 103 p. [In Russian].

Tysovskyi, L. O., Dorundiak, L. M., Liashenyk, A. V., \& Dadak, Yu. R. (2010). Pobudova matematychnoi modeli dlia zadachi pro rukh povitria $\mathrm{v}$ tsykloni. Vseukrainskyi naukovo-tekhnichnyi zhurnal PHiP, 2(28), 57-62. [In Ukrainian].

A. V. Lyashenyk', Ye. M. Lyutyi', L. O. Tysovskyi², Yu. R. Dadak

${ }^{I}$ Kolomyya Polytechnic College Lviv Polytechnic National University, Kolomyya, Ukraine ${ }^{2}$ National Forestry University of Ukraine, Lviv, Ukraine

\section{THEORY AND PRACTICE OF CYCLONE COLLECTOR USE IN THE WOODWORKING INDUSTRY}

The paper describes some characteristics of the main types of cyclone collectors used in the woodworking industry and contains their comparative analysis. The existing approaches to mathematical modeling of aerodynamic processes in cyclone collectors, their drawbacks and benefits are described. A new mathematical model of the polluted air flow inside a separator is created, based on the joint consideration of the Navier-Stokes equations for a viscous compressible liquid (gas), the equation of continuity, state equations and equations of heat balance. The initial and boundary conditions are written for a $\mathrm{CN}-15$ cyclone. They have solved the complete system of differential equations in partial derivatives and studied the influence of the geometric dimensions of the separator (cylinder height, conic height, diameter of the dust nozzle, diameter of the exhaust pipe, submersion depth of the exhaust pipe, distance from the exhaust pipe to the edge of the conical part) on operational parameters of the unit (hydraulic resistance, static pressure). They have also examined the patterns of the velocity field distribution (full, tangential, axial) of the polluted air flow in different sections of the cyclone depending on its geometry. The results of numerical analysis are confirmed by the experimental research; a good coincidence of results is obtained. Based on the proposed mathematical model of aerodynamic processes in the cyclone collector, the feasibility of changing the geometric dimensions of the air cleaner to increase the unit efficiency has been justified. Numerical analysis of the task was conducted for a cyclone with fixed geometric parameters. The dependence of the hydraulic resistance of the cyclone from such parameters as the height of the cylindrical part, the clay exhaust pipe, the height of the conical part, the diameter of the exhaust pipe, the diameter of the saw blade was studied. The research of the distribution of static pressure inside the cyclone body has been carried out. During the research various diameters related to the choice, as well as various values of the height of the cylindrical part were considered. The field of the velocity of the requested flow of the medium saw blade, its tangential and axial component were researched. On the basis of the developed mathematical model, insulations of the flow velocities in characteristic planes passing through the vertical axis of the cyclone were built. To confirm the adequacy of the proposed mathematical model, the results of numerical analysis are confirmed by the experimental research. For this purpose, the design of an experimental test bench has been developed for carrying out research, which provides the possibility of changing the height of the cylindrical part, the depth of the dipping of the exhaust pipe, the cross-sectional area of the exhaust pipe, and the use of different types of conical part of the bunkers.

Keywords: transport pneumatic systems; cyclone collector; polluted air; mathematical modeling of aerodynamic processes; Navier-Stokes equation. 